\title{
Paradise under Construction
}

\section{Christian Sorace}

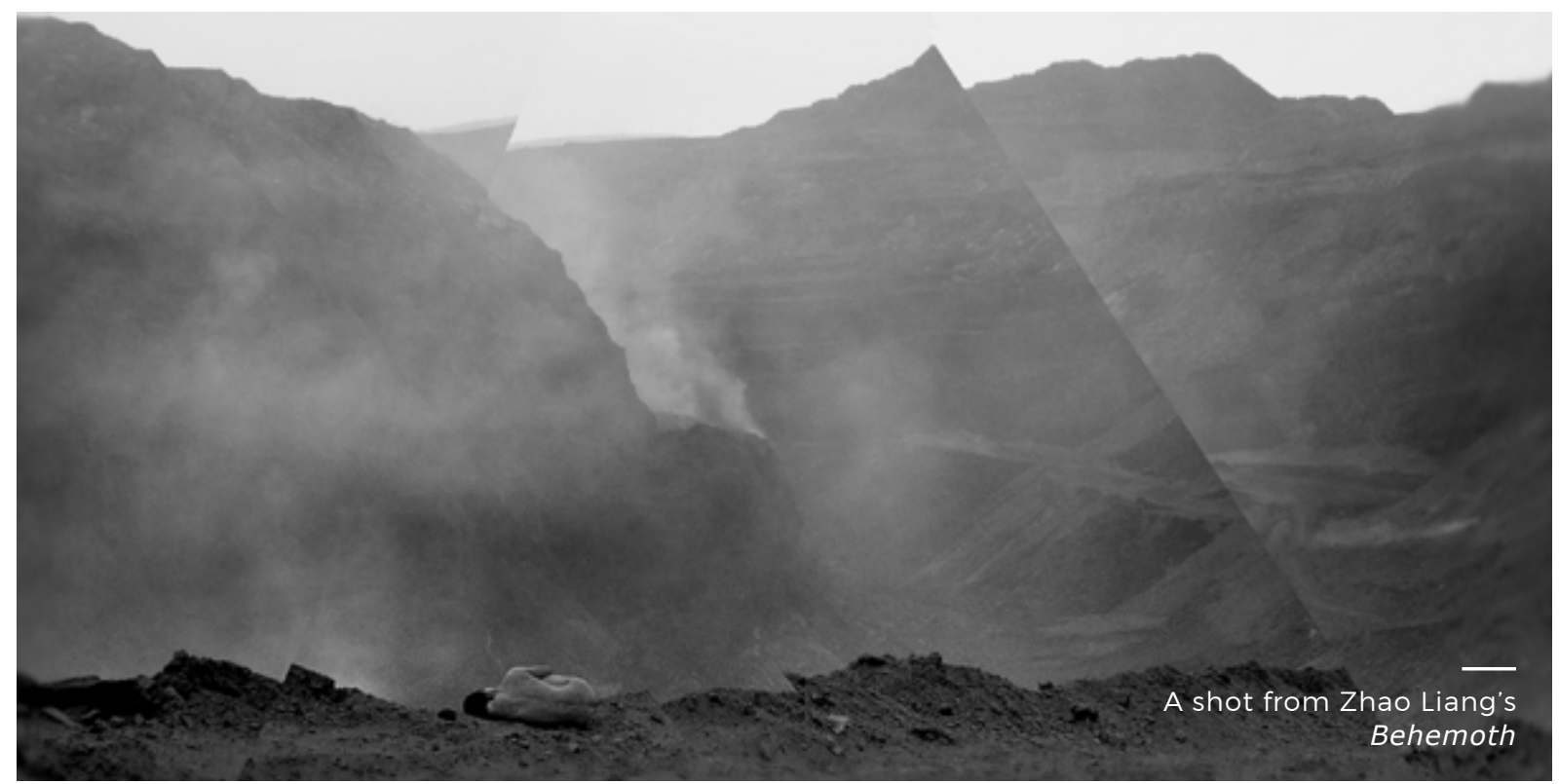

From the earliest times, human civilization has been no more than a strange luminescence growing more intense by the hour, of which no one can say when it will begin to wane and when it will fade away.

W.G. Sebald

Zhao Liang's recent film Behemoth (beixi moshou) is a cinematic meditation on the Anthropocene-the current geological epoch marking 'a new phase in the history of the Earth, when natural forces and human forces become intertwined, so that the fate of one determines the fate of the other.' Composed from documentary footage of natural and human life in their devastated forms, Behemoth offers a dystopian view of our present reality based on a script written by Zhao Liang that is loosely adapted from Dante's Divine Comedy. In an interview I conducted with the director via the popular Chinese social media platform WeChat this past July, taking a studied cynical tone, he described his art as a technique of making the ugly beautiful: "Most of the time, I take some ugly affair and make it "look beautiful" on film. But isn't our world often packaged to appear beautiful in this way, especially politics?'
Zhao Liang's aesthetic style is one of unflinching exposure, however, which shares little in common with the theatricality of state power and mystification of sovereign violence. The gorgeous cinematography of Behemoth creates a new perceptual field of planetary destruction in a way that is unavailable to the prose of scientific description and political argument. As the poet Rainer Maria Rilke famously wrote in his Duino Elegies, 'For beauty is nothing but the beginning of terror, which we are still just able to endure, and we are so awed because it serenely disdains to destroy us. Every angel is terrifying.' We follow the prophetic guide into the Inferno, but we do not come out the same.

The narrative of Behemoth follows what Zhao Liang describes as a 'supply chain' (chanyelian) of urban construction. ${ }^{1}$ The film opens with a long-shot of an open-pit coal mine in Inner Mongolia, explosions 
are heard in the distance, coal ash rains from the sky into the frame, accompanied by the rasping of traditional Mongolian throat-singing. The camera descends into coal mines, swelters in the heat of iron smelting furnaces, dispassionately gazes on coal miners in their dormitories and hospital beds, and finally sojourns in the utopian 'ghost city of Ordos' where the film ends.

For those who are unfamiliar with the context, Ordos is a Prefecture-Level Municipality located in the Gobi Desert in Inner Mongolia. After a natural resource boom beginning in 2004, the Ordos government decided to invest its windfall revenue in the construction of a new administrative capital named Kangbashi in an area that was mostly desolate wasteland. Despite its modern architecture and urban trappings, Kangbashi has failed to attract residents, earning it the reputation of China's most infamous 'ghost city' (gui chengshi). For some China watchers, it is a portent of the inevitable bursting of China's real estate bubble inflated by political incentives and speculative land development. In Behemoth, Kangbashi is described as the 'paradise of our dreams'-a perfect, clean, and empty city.

\section{The Other Side of Urbanisation}

Urbanisation and the extraction of coal, natural gas, and rare earth minerals contribute to the desertification of China's grasslands, which has triggered massive sandstorms that have blown into Beijing and Tianjin. In Behemoth, we witness the scars of urban modernity: craters from open-pit coal mines, vegetation desiccated due to the consumption of surface water by mining operations, billowy clouds of pollution. According to Zhao Liang, filming 'the shattered mountains and rivers and last gasps of life' (posui de shanhe, canchuan de shengming) were the scenes that 'pierced' (citong) him the most.

Part of Behemoth's visual power is its formal treatment of human bodies and natural landscapes as the same damaged matter. The bodies of coal miners belong to the landscape. The camera glides across their creased faces, blistered hands, and bodies covered in the 'inky make-up' soot and sweat. In one scene, we hear the laboured breathing of a coal miner suffering from pneumoconiosis, hooked up to a respiratory apparatus, lying in bed. He is indifferent to the camera's presence. Later, we see a woman holding up a funerary portrait of a man who may or may not have been him.

Even though Behemoth is ostensibly a documentary, none of the miners are given a voice in the film. To some, this may appear as an additional layer of exploitation. For me, however, the decision to exclude biographical details and life trajectories from the film's narrative content allows a different kind of speech to occur.

The silent bodies and gazes of the miners speak of their expendability. A miner's individual life, dreams, and medical records matter little to the coal mining boss, Party secretary, financial speculator, and middle class home-owner. From the standpoint of those who benefit from the urbanisation process, the miner's life is valued as long as he is healthy enough to show up for work. When he can no longer work, he will be replaced. The decision not to give the miners a voice amplifies the singularity of each physical presence in the face of its precarity and serial interchangeability.

Behemoth is about more than 'the human and environmental costs of coal mining and consumption in China' because the word 'cost' remains within a political economy of commensurability. A miner's health is not the 'cost' of his need to survive. The destruction of the planet is not some unfortunate 'price' of modernisation but its suicidal involution. The Anthropocene has moved us beyond the 


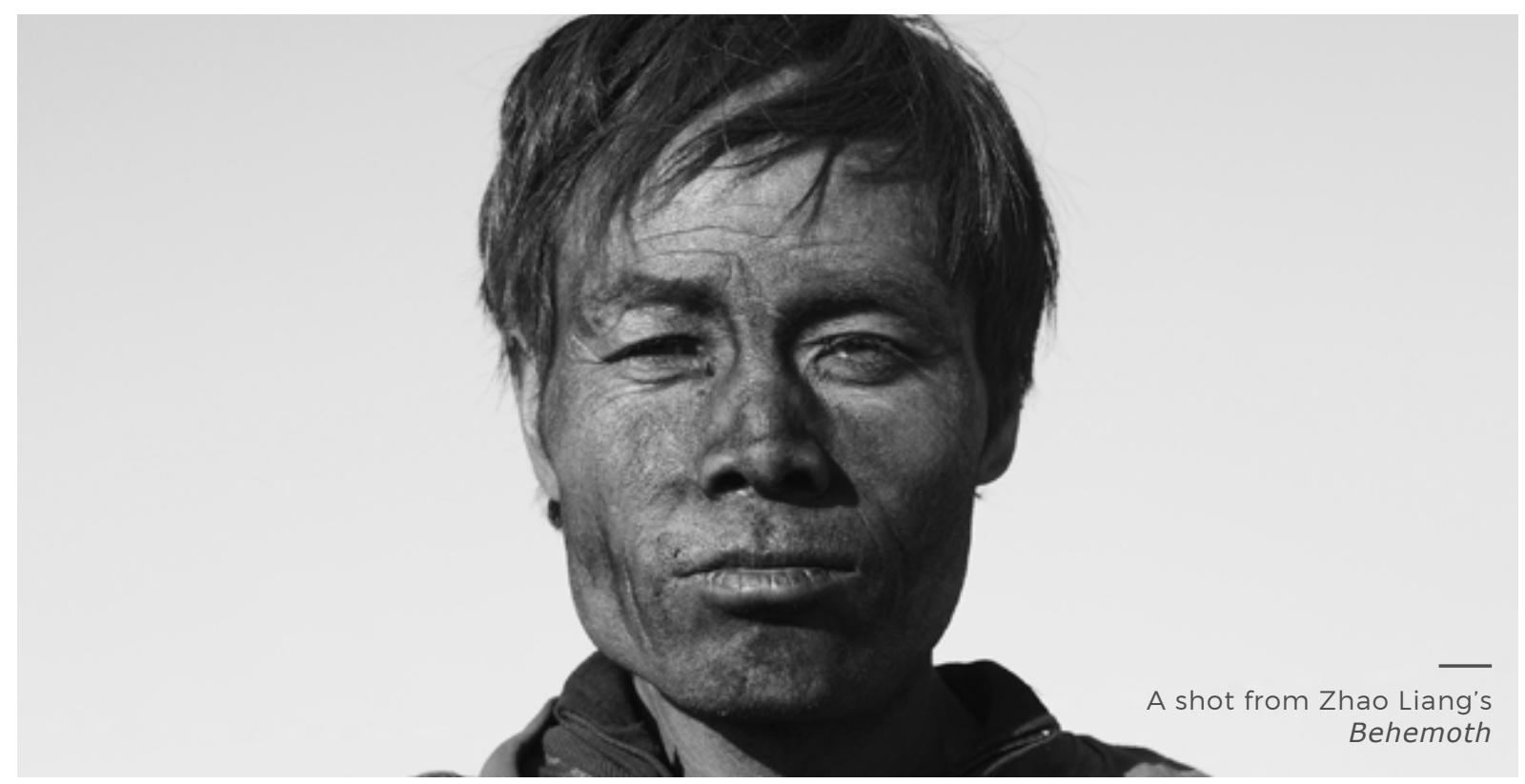

calculation of cost-benefit equivalences into a world where new values, systems, and myths are needed.

As the philosopher Jean-Luc Nancy put it, "Yet we can oppose nothing to "growth" unless we can conceive of another civilization, a new sense of existence not enslaved to production but freed for itself. Which implies that this "for itself" finds its own meaning, the meaning of its "own" fact of being.' The end of capitalism will only be the beginning of a life we have not yet imagined.

\section{After the Promise of Communism}

It is significant that Zhao Liang's dystopian vision of reality takes place in post-socialist China. Twentieth century communism promised an end to exploitation, the emancipation of all human beings, and the liberation of our creative faculties. Instead of achieving these goals, it generated its own forms of lethal oppression and, in doing so, destroyed our ability to dream of a political solution to the inequalities of capitalism. ${ }^{2}$

In a conversation that I had with him at his workshop in Beijing this past June, Zhao Liang referred to 'humanity as a cancer of the earth' (renlei shi diqiu de aizheng). When I asked him why he thought we are 'incurable' (meijiu), his answer was 'original sin' (yuanzui) which he defined as 'the defect of boundless desire' (yuwang de wuxianxing de quexian). He is also increasingly skeptical of the transformative power of art. In an interview from March 2016 with Slant Magazine, the artist recalls feeling 'compelled by social responsibility' when he first started making documentaries but 'no longer' sees his 'work as a catalyst for creating social benefit.' When I asked what precipitated his abandonment of political optimism, his response was the 'cruelty of the real world' and 'powerlessness' to change it (xianshi shijie de cankuxing he wuligan).

Although such arrant nihilism is modish in China's art scene, it is not without historical basis. Zhao Liang's pessimistic view of human nature raises important, unresolved, and unfashionable questions about the failure of China's twentieth century communist project. To put it somewhat coarsely, for all of the Communist Party's laudable as well as violent attempts to 'change the human being in what is most profound', they were unable to eradicate the venality, cruelty, and boundless desire of human nature. 


\section{Art in the Anthropocene}

As McKenzie Wark points out, 'The unspeakable secret about climate change is that nobody really wants to think about it for too long. It's just too depressing.' It is also cognitively impossible to grasp the totality of climate change's complex non-linear temporalities and uneven geographies. Instead, as Jodi Dean argues, it is much easier to circulate platitudes that generate enjoyment in moral outrage and self-exoneration. For these reasons, I suggest that art in the age of the Anthropocene has the power to convey scientific and political truths in images and sensory environments in ways that disturb our complacency, enjoyment, and ignorance.

In China, several contemporary artists have been grappling with the problems posed by the Anthropocene, inventing new aesthetic forms, and creatively working with damaged materialities. In the series of photographs called New Landscapes, Yao Lu re-creates traditional Chinese landscapes of mountains and rivers using trash and debris from landfills. He Xiangyu's Cola Project required boiling thousands of litres of cola, which hardened into a coal-like substance that could be ground into ink and used for Song Dynasty-style landscape paintings. Cai GuoQiang's 2014 exhibit The Ninth Wave included the manufacture of a contemporary Noah's Ark 'carrying 99 fabricated animals in various states of decline' which 'sailed along the Huangpu River' before docking at the Power Station of Art in Shanghai. Cai's ship of tattered stuffed animals followed the same course as $\mathbf{1 6 , 0 0 0}$ dead pigs, which mysteriously floated down the river a year earlier in March 2013. In these works, the mimetic relationship between art and nature becomes recursive as we are no longer able to discern human artifacts from natural processes.

\section{Dreaming from the Ruins}

With unforgettable cinematography and soundscapes, Behemoth reveals the devastation of the Inner Mongolian grasslands due to fossil fuel extraction. The mobility of the camera enables it to traverse, and record, different scales and topographies of damaged matter. It brings into view a dystopian reality that we would otherwise be unable to visualise.

This is not to suggest that art can save us from extinction. Perhaps Zhao Liang's pessimism is correct and humanity is a 'cancer' that will metastasise until we have killed our host. I am not convinced. For me, Behemoth prophesises that it is time to dream of a new paradise that can mobilise the political energy and will to build a world in common from the ruins of the one we have destroyed. It may fail, but it is our only hope.

\footnotetext{
${ }^{[1]}$ This description is from an advertisement on WeChat for a private screening of Behemoth in Beijing. The advertisement was 'harmonised', i.e., deleted, from WeChat and the screening was cancelled.

[2] Today, the Chinese Communist Party officially promises to engineer a 'moderately prosperous society' (xiaokang shehui), and the 'China dream' (Zhongguo meng) is deployed in the service of 'social stability' (weihu shehui wending), capitalist accumulation, and exploitation. They are a far cry from the dreams of universal emancipation and working class power.
}

\section{Christian Sorace}

Christian Sorace is a Postdoctoral Fellow at the Australian Centre on China in the World, Australian National University. He is the author of Shaken Authority: China's Communist Party and the 2008 Sichuan Earthquake, scheduled for publication with Cornell University Press in Spring 2017. He is currently conducting research on the urbanisation of the grasslands in Inner Mongolia, China and ger districts in Ulaanbaatar, Mongolia. 